\title{
Screening Fruit Loosening Agents for Black Ripe Processed Table Olives
}

Jacqueline K. Burns ${ }^{1}$

Horticultural Sciences Department, University of Florida, Institute of Food and Agricultural Sciences, Citrus Research and Education Center, 700 Experiment Station Road, Lake Alfred, FL 33850

Louise Ferguson and Kitren Glozer

Department of Plant Sciences, University of California, Davis, CA 95616

William H. Krueger

University of California Cooperative Extension, Glenn County, Orland, CA 95963

\section{Richard C. Rosecrance \\ College of Agriculture, California State University, Chico, CA 95929}

Additional index words. abscission, 1-Aminocyclopropane-1-carboxylic acid, defoliation, ethephon, mechanical harvest, 1-methylcyclopropene, monopotassium phosphate

\begin{abstract}
The California table olive (Olea europaea L.) industry relies exclusively on hand harvesting of its primary Manzanillo cultivar. Increased harvesting costs have intensified industry interest in identifying an abscission agent that can be used with developing mechanical harvesting technologies to increase removal rates. Table olives are harvested immature green at horticultural maturity but before physiological maturity. The goal of this research was to reevaluate the potential of ethylene-releasing compounds (ERCs) as olive-loosening agents and to screen additional candidates previously shown to accelerate citrus fruit abscission. Eleven compounds were screened at two separate table olivegrowing sites (Fresno and Tehama counties) in California in September until Nov. 2006. Compounds were applied at various concentrations alone or in combination. Fruit detachment force (FDF) and percent fruit drop were measured and leaf loss assessed. Of the compounds evaluated, the ERC ethephon (2-chloroethyl phosphonic acid) and 1-aminocyclopropane-1-carboxylic acid were the most efficacious. In whole tree applications, concentrations of ethephon or 1-aminocyclopropane-1-carboxylic acid above $1000 \mathrm{mg} \cdot \mathrm{L}^{-1}$ reduced $\mathrm{FDF}$ to less than $50 \%$ of the untreated control within 17 days, but leaf drop increased with increasing concentrations. Addition of 1-methylcyclopropene reduced efficacy of ethephon and delayed leaf drop. Monopotassium phosphate + ethephon (4\% and $1000 \mathrm{mg} \cdot \mathrm{L}^{-1}$, respectively) reduced FDF and leaf loss was equivalent to the ethephon alone treatment. Compounds such as methyl jasmonate, coronatine, dikegulac, MAXCEL, traumatic acid, and 5-chloro-3-methyl-4-nitro-1H-pyrazole were not efficacious.
\end{abstract}

Olives (Olea europaea L.) are commercially grown throughout the world in areas of Mediterranean climate. Cultivation is primarily for oil and table olive products. In the United States, California is the only state with commercial olive orchards and in 2000 to 2002 accounted for $\approx 7 \%$ of total world table olive production (Connell, 2005). The California olive industry relies almost exclusively on the table olive.

Table olives are harvested immature green at horticultural maturity but before physiological maturity (Ferguson et al., 2005). Harvest is done by hand labor over a period of $\approx 2$ months. Increased labor costs and low labor availability have intensified

Received for publication 13 Aug. 2007. Accepted for publication 24 Sept. 2007.

We acknowledge the contributions of Valent BioSciences.

${ }^{1}$ To whom reprint requests should be addressed; e-mail jkbu@ufl.edu industry interest in mechanical harvesting. Unusually low temperatures during flower bud initiation in Feb. 2006 in California's Central Valley olive production areas markedly reduced yield in a year when lower yield was expected as a result of alternate bearing. Extremely low yield combined with labor pressures increased harvesting costs further and strained olive inventories at the processing plant. To ensure future economic stability for the olive grower and consistent product flow at the processing plant, the California table olive industry has viewed the development of a successful mechanical harvesting system, that is, mechanical harvesting combined with abscission agent application (Burns et al., 2005), as a high priority.

Trunk-shaking mechanical harvesters were evaluated in the past but unable to harvest table olive fruit efficiently and without damage (Ferguson et al., 2005). Canopyshaking mechanical harvesters are being developed currently and show promise. How- ever, a fruit-specific abscission agent would allow for higher fruit removal. Moreover, an abscission agent would enable lower mechanical forces to be applied during harvest, thus minimizing fruit damage. Fruit damage is an industry concern because bruising may compromise quality of the final canned product, although this remains to be tested.

Abscission agents were applied experimentally to olive canopies in the past to improve fruit removal by trunk-shaking mechanical harvesters (Martin, 1994). Of those tested, only ethylene-releasing compounds (ERCs) such as ethephon (2-chloroethyl phosphonic acid) achieved consistent fruit loosening (Hartmann et al., 1970; Martin et al., 1981). ERC use in many crops, including olive, has been problematic as a result of attendant leaf loss coincident with fruit loosening. Treatments designed to minimize unwanted defoliation such as calcium application (Martin et al., 1981), or alteration in ERC application timing and duration (Lang and Martin, 1985, 1989), were promising in a laboratory setting but unpredictable in the field (Martin, 1994). Recent work in Florida identified compounds that accelerated mature and immature fruit abscission when applied to citrus canopies in the field (Burns, 2002). In this work, we describe efficacy of several of these compounds and reevaluate the potential of ethephon for olive fruit loosening.

\section{Materials and Methods}

Olive screening trials were located at two separate sites in California. At each site, fruit were deemed ready for harvest as table olives based on color change from green to straw and appearance of characteristic white milky juice from fruit when squeezed (Ferguson et al., 2005). Fruit detachment force (FDF) was measured at various times up to $17 \mathrm{~d}$ after application using an Imada DPA-11 digital force gauge (Imada, Northbrook, IL). At various times, treated branches were removed and brought to the laboratory. Olive fruit were clipped from branches to include at least $1-\mathrm{cm}$ pedicel, inserted into the gauge, and the pedicel pulled parallel to the fruit axis until it separated from the fruit. The force necessary to remove fruit from the pedicel was measured in grams of force.

\section{Fresno county site}

Trials were initiated on four separate dates in late September to mid-Oct. 2006 at an experimental orchard located at the University of California's Kearney Agricultural Center, Parlier, CA. Trees were 12 years of age. Varieties used were 'Rigali' on its own roots, 'Manzanillo' on 'Rigali' rootstock, and 'Mission' on 'Manzanillo' rootstock. For each of the four trials described below, three replicate branches were selected on one tree of each variety, giving an overall total of nine replicates for each treatment. Each branch was considered an experimental unit and contained at least eight fruit and 25 leaves. Treatments were randomly assigned 
Table 1. The effect of putative abscission agents on fruit detachment force (FDF, grams of force) and fruit drop (\%) in olive treated on the dates indicated in $2006^{2}$.

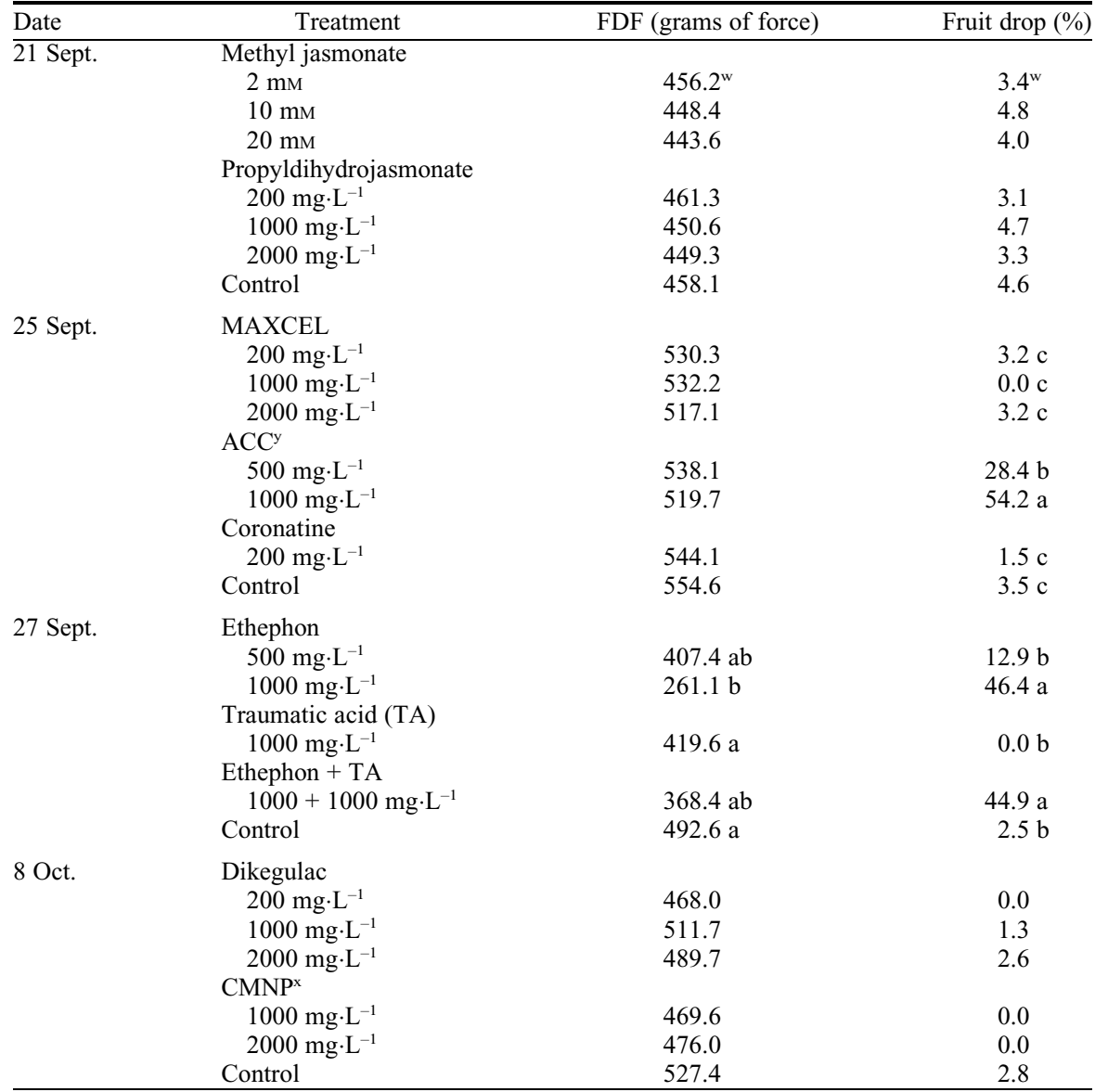

${ }^{2}$ Branch tests were conducted in Fresno county, CA.

${ }^{\mathrm{y}} \mathrm{ACC}=1$-aminocyclopropane-1-carboxylic acid

${ }^{\mathrm{x}} \mathrm{CMNP}=3$-chloro-5-methyl-4-nitro-1 $H$-pyrazole.

wMeans within each date and column followed by the same letter are not significantly different $(P \leq 0.05)$.

Absence of letters within each date and column indicates no statistical significance found.

to branches, and the number of fruit on each branch was recorded. Abscission compounds were dissolved in water containing $0.05 \%$ Kinetic organosilicate adjuvant (Setre Chemical Co., Memphis, TN). A water control was included in all trials. Treatments were applied between 1030 and $1400 \mathrm{HR}$ with a handheld 1.5-L pressurized sprayer until runoff. FDF was measured 7 or $12 \mathrm{~d}$ after application. Percentage fruit drop was computed by counting the number of fruit that dropped from the branch at the end of the experiment, dividing by the total number of fruit at the beginning of the trial, and multiplying by 100 . Data were analyzed as a completely randomized design. Analysis of variance and Duncan's mean separation were used to test significance between treatment means. Percentage data were transformed using arcsine transformation when necessary to stabilize variance.

Trial 1. On 21 Sept. 2006, branches were sprayed with 2,10 , or $20 \mathrm{~mm}$ methyl jasmonate (MJ; Bedoukian Research, Inc., Danbury, CT) or 200,1000 , or $2000 \mathrm{mg} \cdot \mathrm{L}^{-1}$ propyldihydrojasmonate (Valent BioSciences Corp., Libertyville, IL). Maximum, minimum, and average temperatures on the day of application were 85,54 , and $69^{\circ} \mathrm{F}(29,12$, and $20^{\circ} \mathrm{C}$ ), respectively. Average maximum, minimum, and overall average temperatures for the duration of the trial were 83,53 , and $67{ }^{\circ} \mathrm{F}\left(28,11\right.$, and $\left.19^{\circ} \mathrm{C}\right)$, respectively. FDF and fruit drop measurements were taken $12 \mathrm{~d}$ after application.

Trial 2. On 25 Sept. 2006, branches were sprayed with 200,1000 , or $2000 \mathrm{mg} \cdot \mathrm{L}^{-1}$ 6-benzyladenine (MAXCEL; Valent BioSciences Corp.); 500 or $1000 \mathrm{mg} \cdot \mathrm{L}^{-1}$ 1-aminocyclopropane-1-carboxylic acid (ACC; Sigma-Aldrich, St. Louis, MO.); or 200 $\mathrm{mg} \cdot \mathrm{L}^{-1}$ coronatine [fermented, extracted, and quantified according to Burns et al. (2003)]. Maximum, minimum, and average temperatures on the day of application were 92,48 , and $69^{\circ} \mathrm{F}\left(33,8\right.$, and $\left.20^{\circ} \mathrm{C}\right)$, respectively. Average maximum, minimum, and overall average temperatures for the duration of the trial were 79,52 , and $65^{\circ} \mathrm{F}$ $\left(26,11\right.$, and $\left.18{ }^{\circ} \mathrm{C}\right)$, respectively. FDF and fruit drop measurements were taken $12 \mathrm{~d}$ after application.

Trial 3. On 27 Sept. 2006, branches were sprayed with $1000 \mathrm{mg} \cdot \mathrm{L}^{-1}$ traumatic acid (TA; Sigma-Aldrich Co.); 500 or 1000 $\mathrm{mg} \cdot \mathrm{L}^{-1}$ ethephon (Ethrel; Aventis Crop Science, Research Triangle Park, NC); or TA + ethephon $\left(1000+1000 \mathrm{mg} \cdot \mathrm{L}^{-1}\right)$. Maximum, minimum, and average temperatures on the day of application were 90,53 , and $69^{\circ} \mathrm{F}(32$, 11 , and $20^{\circ} \mathrm{C}$ ), respectively. Average maximum, minimum, and overall average temperatures for the duration of the trial were 78,52 , and $64{ }^{\circ} \mathrm{F}\left(25,11\right.$, and $\left.17{ }^{\circ} \mathrm{C}\right)$, respectively. FDF and fruit drop measurements were taken $12 \mathrm{~d}$ after application.

Trial 4. On 8 Oct. 2006, branches were sprayed with 200,1000 , or $2000 \mathrm{mg} \cdot \mathrm{L}^{-1}$ dikegulac (Atrimmec; PBI/Gordon Corp, Kansas City, MO); or 1000 or $2000 \mathrm{mg} \cdot \mathrm{L}^{-1}$ 5-chloro-3-methyl-4-nitro-1 $H$-pyrazole (CMNP; previously formulated by Abbott Laboratories, Libertyville, IL). Maximum, minimum, and average temperatures on the day of application were 78,49 , and $62^{\circ} \mathrm{F}(25$, 9 , and $\left.16^{\circ} \mathrm{C}\right)$, respectively. Average maximum, minimum, and overall average temperatures for the duration of the trial were 78,52 , and $64^{\circ} \mathrm{F}\left(25,11\right.$, and $\left.17^{\circ} \mathrm{C}\right)$, respectively. As a result of time constraints, FDF and fruit drop measurements were taken $7 \mathrm{~d}$ after application.

\section{Tehama county site}

A trial was initiated on 24 Oct. 2006 in a commercial olive orchard located 5 miles $(8 \mathrm{~km})$ northwest of Corning, CA. Fortyseven uniform 7-year-old 'Manzanillo' trees on their own roots were selected and treatments randomly assigned. Fifteen treatments were applied to three trees each. All spray treatments included $0.05 \%$ Silwet adjuvant. Spray applications were done using a 200 gallon (757-L) tank equipped with a pressurized handgun until runoff. Treatments were $500,1000,1500$, or $2000 \mathrm{mg} \cdot \mathrm{L}^{-1}$ ethephon; 5 mм 1-MCP (as SmartFresh; AgroFresh, Philadelphia, PA); 1000,1500 , or $2000 \mathrm{mg} \cdot \mathrm{L}^{-1}$ ethephon $+5 \mathrm{~mm} 1-\mathrm{MCP} ; 500,1000$, or 2000 $\mathrm{mg} \cdot \mathrm{L}^{-1}$ ACC, $4 \%$ monopotassium phosphate (MPK; MORA-LEAF P\&K; Wilbur Ellis, Fresno, CA) with and without $1000 \mathrm{mg} \cdot \mathrm{L}^{-1}$ ethephon; and a water and untreated control. Maximum, minimum, and average temperatures on the day of application were 86,46 , and $63{ }^{\circ} \mathrm{F}\left(30,8\right.$, and $\left.17^{\circ} \mathrm{C}\right)$, respectively. A representative branch from each replicate tree was removed 3, 6, 10, 13, and $17 \mathrm{~d}$ after application. Branches were transported to the Glenn County Cooperative Extension Office in Orland, CA, and FDF was measured as described above. Defoliation was evaluated in the orchard using a subjective leaf abscission score (LAS) of 0 (no defoliation), 1 (light defoliation), 2 (moderate defoliation), and 3 (severe defoliation, greater than $50 \%$ canopy volume). Average maximum, minimum, and overall average temperatures for the duration of the trial were 74,49 , and $61^{\circ} \mathrm{F}$ $\left(23,9\right.$, and $\left.16{ }^{\circ} \mathrm{C}\right)$, respectively. Data were analyzed as a completely randomized design. Analysis of variance and Duncan's mean separation were used to test significance between treatment means.

\section{Results}

Fresno county site. The varietal effect was not significant in each trial, so data from 
the three varieties were pooled. MJ, propyldihydrojasmonate, MAXCEL, coronatine, TA, and CMNP had no effect on FDF or percent fruit drop at any concentration tested (Table 1). Only treatment with $1000 \mathrm{mg} \cdot \mathrm{L}^{-1}$ ethephon significantly reduced FDF when compared with control fruit. Fruit drop was significantly increased in fruit treated with $1000 \mathrm{mg} \cdot \mathrm{L}^{-1}$ ethephon and the combination treatment of ethephon and TA at $1000 \mathrm{mg} \cdot \mathrm{L}^{-1}$ each. Although 500 and $1000 \mathrm{mg} \cdot \mathrm{L}^{-1}$ ACC significantly increased fruit drop, FDF was not altered. In this case, loosening and fruit drop likely occurred before FDF was measured, and the remaining fruit either did not respond to the compound or the partially digested abscission zones reformed or "healed".

Tehama county site. Application of 1500 and $2000 \mathrm{mg} \cdot \mathrm{L}^{-1}$ ethephon reduced FDF as days after application increased (Fig. 1A). Concentrations below $1500 \mathrm{mg} \cdot \mathrm{L}^{-1}$ were not as effective. By day 17, FDF in fruit treated with 1500 and $2000 \mathrm{mg} \cdot \mathrm{L}^{-1}$ were statistically lower than any other treatment, whereas lower ethephon concentrations were no different from the control. ACC reduced FDF as days after application increased (Fig. 1B). Like ethephon, ACC application at 2000 $\mathrm{mg} \cdot \mathrm{L}^{-1}$ gave significantly lower FDF values when compared with other ACC concentrations. After day 6, LAS increased in all ethephon and ACC treatments (Fig. 1C-D). LAS was significantly greater at the highest concentration compared with the other concentrations tested. At comparable concentrations of 500 and $1000 \mathrm{mg} \cdot \mathrm{L}^{-1}, \mathrm{ACC}$ application resulted in significantly lower FDF readings than ethephon (Table 2). However, no statistical difference between ACC and ethephon was measured when either was applied at $2000 \mathrm{mg} \cdot \mathrm{L}^{-1}$. Despite higher efficacy attributed to ACC at comparable concentrations, there was no statistical difference in LAS. Ethephon at $1000 \mathrm{mg} \cdot \mathrm{L}^{-1}+4 \% \mathrm{MPK}$ significantly lowered FDF when compared with ethephon or MPK alone after $17 \mathrm{~d}$; however, LAS was not significantly different (Fig. 2).

To reduce unwanted leaf drop associated with ethephon applications, $5 \mathrm{~mm} 1-\mathrm{MCP}$ was combined with ethephon in the spray tank and applied to olive canopies. At all ethephon concentrations, 1-MCP delayed ethephon-induced leaf drop (data not shown). Leaf drop $17 \mathrm{~d}$ after application was low when 1000 or $1500 \mathrm{mg} \cdot \mathrm{L}^{-1}$ ethephon was used, and 1-MCP had no effect (Table 3). However, 1-MCP significantly lowered leaf drop associated with $2000 \mathrm{mg} \cdot \mathrm{L}^{-1}$ ethephon application. Ethephon-induced olive fruit loosening was delayed by 1-MCP (data not shown). After $17 \mathrm{~d}$, however, there were no significant differences in FDF when 1-MCP was applied.

\section{Discussion}

ERCs such as ethephon have been used in an attempt to accelerate fruit abscission. After decades of research with ethephon done
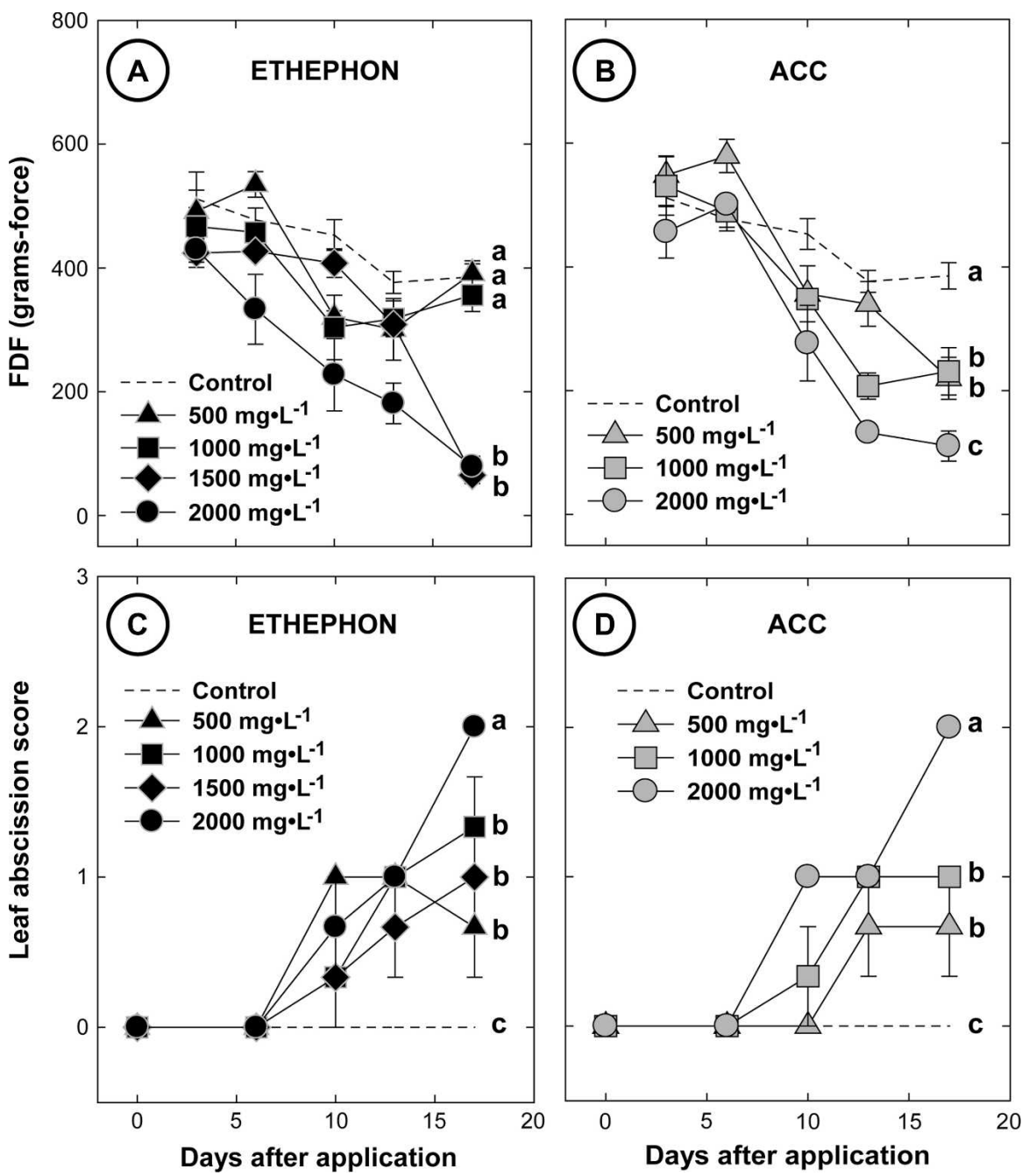

Fig. 1. Change in fruit detachment force (FDF in grams of force, $\mathbf{A}-\mathbf{B})$ and leaf abscission score (C-D) of olive up to $17 \mathrm{~d}$ after treatment with indicated concentrations of (A and $\mathbf{C})$ ethephon and (B and $\mathbf{D})$ 1-aminocyclopropane-1-carboxylic acid (ACC). Adjuvant-treated trees served as controls. Leaf abscission scores range from 0 (no defoliation) to 3 (severe defoliation). Whole tree tests were conducted in Tehama county, CA. Application date was 24 Oct. 2006. Data plotted are the means \pm SE. Analysis of variance and Duncan's mean separation test performed on d 17 data. Means followed by the same letter are not significantly different $(P \leq 0.05)$.

for the purpose of adapting fruit crops for mechanical harvesting, commercial application remains restricted to cherries (Bukovac, 1979) and walnuts (Ramos, 1997). Cherries and walnuts grown for processed markets can be sprayed with ethephon before mechanical harvesting to loosen fruit and increase fruit removal. Significant research effort was spent on adapting olives for mechanical harvesting using ethephon. Although mechanical fruit removal approached $85 \%$ in some cultivars, the 'Manzanillo' olive, important to the current California table olive industry, was particularly prone to excessive leaf loss at ethephon concentrations necessary to accelerate fruit loosening (Martin et al., 1981). Furthermore, ethephon-dependent fruit loosening and leaf loss in olive was influenced by temperature and irrigation practices (Klein et al., 1978; Martin et al., 1981). Excessive temperatures and water stress at the time of application improved ethephon efficacy but also accelerated unwanted leaf loss and phytotoxicity (Bukovac, 1979;
Table 2. Comparison of ethephon and 1-aminocyclopropane-1-carboxylic acid (ACC) application at indicated concentrations on fruit detachment force (FDF, grams of force) and leaf abscission score (LAS) of olive $17 \mathrm{~d}$ after application ${ }^{2}$.

\begin{tabular}{llcl}
\hline $\begin{array}{l}\text { Concn } \\
\left(\mathrm{mg} \cdot \mathrm{L}^{-1}\right)\end{array}$ & $\begin{array}{c}\text { Abscission } \\
\text { agent }\end{array}$ & $\begin{array}{c}\text { FDF } \\
\text { (grams of force) }\end{array}$ & LAS $^{\mathrm{y}}$ \\
\hline 500 & ACC & $219.9 \mathrm{~b}^{\mathrm{x}}$ & $0.7^{\mathrm{x}}$ \\
& Ethephon & $391.1 \mathrm{a}$ & 0.7 \\
& Water control & $401.2 \mathrm{a}$ & 0.0 \\
1000 & ACC & $231.3 \mathrm{~b}$ & $1.0 \mathrm{a}$ \\
& Ethephon & $356.3 \mathrm{a}$ & $1.3 \mathrm{a}$ \\
& Water control & $401.2 \mathrm{a}$ & $0.0 \mathrm{~b}$ \\
2000 & ACC & $110.5 \mathrm{~b}$ & $2.0 \mathrm{a}$ \\
& Ethephon & $79.3 \mathrm{~b}$ & $2.0 \mathrm{a}$ \\
& Water control & $401.2 \mathrm{a}$ & $0.0 \mathrm{~b}$ \\
\hline
\end{tabular}

${ }^{2}$ Whole tree tests were conducted in Tehama county, CA. Application date was 24 Oct. 2006.

${ }^{y}$ LAS range from 0 (no defoliation) to 3 (severe defoliation).

${ }^{x}$ Means within each concentration and column followed by the same letter are not significantly different $(P \leq 0.05)$. Absence of letters within each date and column indicates no statistical significance found. 

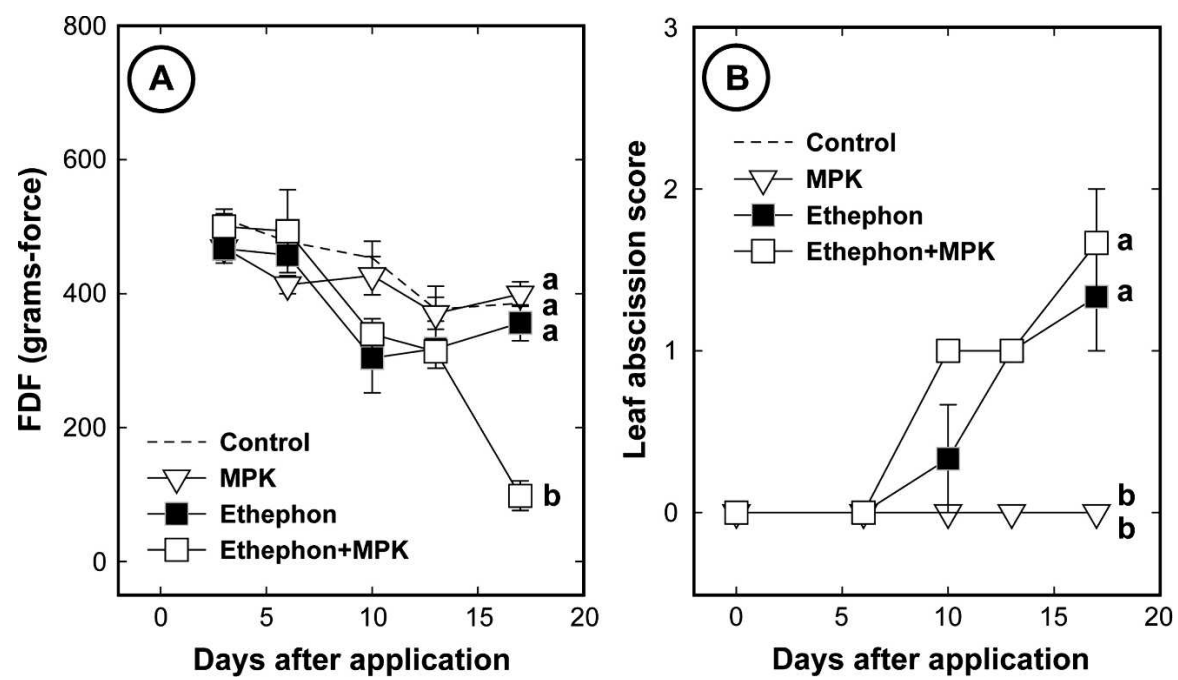

Fig. 2. Change in fruit detachment force (FDF in grams of force, $\mathbf{A}$ ) and leaf abscission score (B) of olive up to $17 \mathrm{~d}$ after treatment with $4 \%$ monopotassium phosphate (MPK), $1000 \mathrm{mg} \cdot \mathrm{L}^{-1}$ ethephon, or $4 \%$ $\mathrm{MPK}+1000 \mathrm{mg} \cdot \mathrm{L}^{-1}$ ethephon. Adjuvant-treated trees served as controls. Leaf abscission scores range from 0 (no defoliation) to 3 (severe defoliation); MPK alone and adjuvant controls had a leaf abscission score of 0 throughout the course of the experiment. Whole tree tests were conducted in Tehama county, CA. Application date was 24 Oct. 2006. Data plotted are the means \pm SE. Analysis of variance and Duncan's mean separation test performed on d 17 data. Means followed by the same letter are not significantly different $(P \leq 0.05)$

Table 3. Comparison of ethephon at indicated concentrations alone or in combination with $5 \mathrm{~mm}$ 1-methylcyclopropene (1-MCP) on fruit detachment force (FDF, grams of force) and leaf abscission score (LAS) of olive $17 \mathrm{~d}$ after application ${ }^{\mathrm{z}}$.

\begin{tabular}{llrr}
\hline Concn $\left(\mathrm{mg} \cdot \mathrm{L}^{-1}\right)$ & Abscission agent & FDF (grams of force) & LAS $^{\mathrm{y}}$ \\
\hline 1000 & Ethephon & $356.3^{\mathrm{x}}$ & $1.3 \mathrm{a}^{\mathrm{x}}$ \\
& Ethephon $+1-\mathrm{MCP}$ & 387.8 & $1.0 \mathrm{a}$ \\
& Water control & 401.2 & $0.0 \mathrm{~b}$ \\
1500 & Ethephon & $65.2 \mathrm{~b}$ & $1.0 \mathrm{a}$ \\
& Ethephon $+1-\mathrm{MCP}$ & $174.3 \mathrm{~b}$ & $1.0 \mathrm{a}$ \\
& Water control & $401.2 \mathrm{a}$ & $0.0 \mathrm{~b}$ \\
2000 & Ethephon & $79.3 \mathrm{c}$ & $2.0 \mathrm{a}$ \\
& Ethephon + 1-MCP & $147.7 \mathrm{~b}$ & $0.3 \mathrm{~b}$ \\
& Water control & $401.2 \mathrm{a}$ & $0.0 \mathrm{~b}$ \\
\hline
\end{tabular}

${ }^{\mathrm{z}}$ Whole tree tests were conducted in Tehama county, CA. Application date was 24 Oct. 2006.

${ }^{y}$ LAS range from 0 (no defoliation) to 3 (severe defoliation).

${ }^{\mathrm{x}}$ Means within each concentration and column followed by the same letter are not significantly different $(P \leq 0.05)$. Absence of letters within each date and column indicates no statistical significance found.

Pozo and Burns, 2000; Yuan and Burns, 2004).

In the work reported here, only the ERC ethephon or the ethylene biosynthetic precursor ACC significantly reduced olive FDF in the field. ACC is converted to ethylene rapidly upon uptake, providing a significant but transient source of ethylene to treated tissues. ACC was shown to promote leaf ethylene production without causing significant leaf loss in olive explants (Martin et al., 1981), suggesting that canopy applications may minimize leaf loss while at the same time accelerate fruit abscission. Although ACC was as effective as or better than ethephon in promoting fruit loosening, leaf loss was high with both compounds.

The ethylene perception inhibitor 1-MCP was shown to reduce unwanted defoliation caused by ethephon without impacting desirable fruit loosening in citrus (Pozo et al., 2004b). This differential action of 1-MCP on mature fruit and leaves may be the result of duration of 1-MCP exposure or differential sensitivity (Burns, 2007). In olive, no benefit of 1-MCP application was seen at low ethephon concentrations, but leaf loss was significantly reduced when 1-MCP was included in the $2000 \mathrm{mg} \cdot \mathrm{L}^{-1}$ ethephon application. Whether defoliation was inhibited or delayed by 1-MCP beyond the trial reported here was not evaluated per se, but visual assessment of the site after 6 months indicated no further leaf loss or longlasting effect on tree health. FDF was reduced by combined ethephon + 1-MCP treatment, but for the purpose of mechanical harvesting, the minimal effect on efficacy may not impair the potential for mechanical fruit removal. A $50 \%$ reduction in FDF was necessary to maximize machine removal of citrus (Burns et al., 2005). Based on these results, further research with ethephon + 1-MCP combinations is warranted.

Banno et al. (1993) demonstrated that phosphorus-containing compounds such as potassium-phosphate buffer accelerated olive fruit abscission with minimal leaf loss.
Goren et al. (1998) attributed phosphoruscontaining buffer-induced abscission to ethylene production by treated tissues, most notably with leaves. MPK at 3\% combined with $500 \mathrm{mg} \cdot \mathrm{L}^{-1}$ ethephon reduced olive FDF by $40 \%$ and increased machine removal of oil olives in Spain (Barranco et al., 2004). In our work with California table olives, greater than $75 \%$ reduction in FDF was achieved with combination application of 4\% MPK + $1000 \mathrm{mg} \cdot \mathrm{L}^{-1}$ ethephon, and leaf loss was no greater than $1000 \mathrm{mg} \cdot \mathrm{L}^{-1}$ ethephon alone. These results indicate that additional trials should focus on MPK + ethephon combinations that maximize FDF and minimize defoliation.

Traumatic acid, an oxidation product of polyunsaturated fatty acids with plant growth regulator activity (Zimmerman and Coudron, 1979), was shown to induce abscission in cotton leaf explants (Strong and Kruttwagen, 1967). TA application alone slightly reduced citrus FDF, but efficacy was improved in a synergistic manner when combined with ethephon (Burns and Pozo, unpublished results). TA had no effect on olive FDF, and combining TA with ethephon did not improve efficacy compared with ethephon alone.

Other abscission agents screened in this work were not efficacious. Methyl jasmonate and coronatine were efficacious in citrus (Burns et al., 2003; Hartmond et al., 2000) and grape (Fidelibus et al., 2007) but not olive. Dikegulac and CMNP caused mature fruit abscission in citrus (Burns, 2002; Pozo et al., 2004a) but had little effect on grape (Fidelibus et al., 2007) and no effect on olive. The basis of the differential response of these fruit types is unknown; however, the table olive is harvested immature, whereas grape and citrus are harvested at, or close to, physiological maturity (Ferguson et al., 2005; Spiegel-Roy and Goldschmidt, 1996; Winkler et al., 1974). It is well known that induction and acceleration of abscission is dependent upon the appropriate developmental and environmental cues (Bleecker and Patterson, 1997). The anatomical development of the immature olive fruit abscission zone at the time of commercial harvest may be incomplete (Reed and Hartmann, 1976) or have reduced tissue sensitivity and, thus, the ability to respond to abscission agents (Trewavas, 1986), thereby attenuating or inhibiting response to applied abscission agents. Furthermore, uptake may be influenced by physiological maturity, fruit position, and tissue composition (Ben-Tal, 1992).

In conclusion, trials were conducted at two separate California table olive-growing sites in 2006. We demonstrated that ACC and ethephon alone or in combination with MPK loosened olive fruit destined for the table olive market. Our future work will focus on maximizing the potential of these agents for olive mechanical harvesting and further screening of additional candidates. In this context, an acceptable abscission agent would selectively and predictably loosen 
olive fruit and minimize leaf loss with no phytotoxicity and no impact on quality of the final product.

\section{Literature Cited}

Banno, K., G.C. Martin, and R.M. Carlson. 1993. The role of phosphorus as an abscission-inducing agent for olive leaves and fruit. J. Amer. Soc. Hort. Sci. 118:599-604.

Barranco, D., O. Arquero, C. Navarro, and H.F. Rapoport. 2004. Monopotassium phosphate for olive fruit abscission. HortScience 39:13131314.

Ben-Tal, Y. 1992. Quantification of ethephon requirements for abscission in olive fruits. Plant Growth Regulat. 11:397-403.

Bleecker, A.B. and S.E. Patterson. 1997. Last exit: Senescence, abscission, and meristem arrest in Arabidopsis. Plant Cell 9:1169-1179.

Bukovac, M.J. 1979. Machine-harvest of sweet cherries: Effect of ethephon on fruit removal and quality of the processed fruit. J. Amer. Soc. Hort. Sci. 104:289-294.

Burns, J.K. 2002. Using molecular biology tools to identify abscission materials for citrus. HortScience 37:459-464.

Burns, J.K. 2007. 1-Methylcyclopropene applications in preharvest systems-Focus on citrus. HortScience 43:112-114.

Burns, J.K., R.S. Buker, and F.M. Roka. 2005. Mechanical harvesting capacity in sweet orange is increased with an abscission agent. HortTechnology 15:758-765.

Burns, J.K., L.V. Pozo, C.R. Arias, B. Hockema, V. Rangaswamy, and C. Bender. 2003. Coronatine and abscission in citrus. J. Amer. Soc. Hort. Sci. 128:309-315.

Connell, J.H. 2005. History and scope of the olive industry, p. 1-10. In: Sibbett, G.S., L. Ferguson, J.L. Coviello, and M Lindstrand (eds.). Olive production manual. University of California Agriculture and Natural Resources Publication 3353.
Ferguson, L., K. Klonsky, and G.C. Martin. 2005. The olive harvest, p. 135-140. In: Sibbett, G.S., L. Ferguson, J.L. Coviello, and M Lindstrand (eds.). Olive production manual. University of California Agriculture and Natural Resources Publication 3353.

Fidelibus, M.W., K.A. Cathline, and J.K. Burns. 2007. Identification of abscission agents for raisin, table and wine grapes. HortScience 42 : 1626-1630.

Goren, R., M. Huberman, and G.C. Martin. 1998. Phosphorus-induced leaf abscission in detached shoots of olive and citrus. J. Amer. Soc. Hort. Sci. 123:545-549.

Hartmann, H.T., A. Tombesi, and J. Whisler. 1970. Promotion of ethylene evolution and fruit abscission in the olive by 2-chloroethanephosphonic acid and cycloheximide. J. Amer. Soc. Hort. Sci. 95:635-640.

Hartmond, U., R. Yuan, J.K. Burns, A. Grant, and W.J. Kender. 2000. Citrus fruit abscission induced by methyl jasmonate. J. Amer. Soc. Hort. Sci. 125:547-552.

Klein, I., E. Epstein, S. Lavee, and Y. Ben-Tal. 1978. Environmental factors affecting ethephon in olive. Scientia Hort. 9:21-30.

Lang, G.A. and G.C. Martin. 1985. Ethylenereleasing compounds and the laboratory modeling of olive fruit abscission vs. ethylene release. J. Amer. Soc. Hort. Sci. 110:207-211.

Lang, G.A. and G.C. Martin. 1989. Olive organ abscission: Fruit and leaf response to applied ethylene. J. Amer. Soc. Hort. Sci. 114:134 138.

Martin, G.C. 1994. Mechanical olive harvest: Use of fruit loosening agents. Acta Hort. 356:284 291.

Martin, G.C., S. Lavee, and G.S. Sibbett. 1981. Chemical loosening agents to assist mechanical harvest of olive. J. Amer. Soc. Hort. Sci. 106:325-330.

Pozo, L. and J.K. Burns. 2000. Ethylene action inhibitors reduced Ethrel-induced leaf drop and gummosis in citrus. Proc. Intl. Soc. Citricult. IX Congr. 1:578-579.

Pozo, L., A. Redondo, U. Hartmond, W.J. Kender, and J.K. Burns. 2004a. 'Dikegulac' promotes abscission in citrus. HortScience 39:16551658.

Pozo, L., R. Yuan, I. Kostenyuk, F. Alferez, G.Y. Zhong, and J.K. Burns. 2004b. Differential effects of 1-methylcyclopropene on citrus leaf and mature fruit abscission. J. Amer. Soc. Hort. Sci. 129:473-478.

Ramos, D.E. 1997. Walnut production manual. University of California Agriculture and Natural Resources Publication 3373.

Reed, N. and H.T. Hartmann. 1976. Histochemical and ultrastructural studies of fruit abscission in the olive after treatment with 2-chloroethyltris-(2-methoxy)-silane. J. Amer. Soc. Hort. Sci. 101:633-637.

Spiegel-Roy, P. and E.E. Goldschmidt. 1996. Biology of horticultural crops. Biology of citrus. Cambridge University Press, Cambridge, UK.

Strong, F.E. and E. Kruttwagen. 1967. Traumatic acid: An accelerator of abscission in cotton explants. Nature 215:1380-1381.

Trewavas, A.J. 1986. Understanding the control of plant development and the role of growth substances. J. Plant Physiol. 13:447-457.

Winkler, A.J., J.A. Cook, W.M. Kliewer, and L.A. Lider. 1974. General viticulture. University of California Press, Berkeley, CA.

Yuan, R. and J.K. Burns. 2004. Temperature factor affecting the abscission response of mature citrus fruit and leaves to CMN-pyrazole and ethephon in 'Hamlin' oranges. J. Amer. Soc. Hort. Sci. 129:287-293.

Zimmerman, D.C. and C.A. Coudron. 1979. Identification of traumatin, a wound hormone, as 12-oxo-trans-10-dodecenoic acid. Plant Physiol. 63:536-541. 